\title{
Assessment of Tuberose (Polianthes tuberosa L.) cultivars used for spikes production under western Uttar Pradesh conditions
}

\author{
Virendra Pal*, Naveen Chandra and Omvir Singh \\ Krishi Vigyan Kendra, Hastinapur, SVPUAT, Meerut-250110 (U.P.) \\ *Email: dvpgangwar77@gmail.com
}

\begin{abstract}
A field experiment was conducted to assessment the performance of tuberose cultivars used for spikes production under Western Utter Pradesh conditions at Research Farm, under Crop Cafetaria Unit, Krishi Vigyan Kendra, Hastinapur, SVP University of Agriculture \& Technology, Meerut (UP) India during the year 2014-15 and 2015-16. Eight potential various cultivars namely Mexican single, Arka Nirantara, Shringar, Rajat Rekha Pearl double, Suvasini, Vaibhav and Swarn Rekha were performed in a Randomized Complete Block Design (RCBD) with three replication. Tuberose cultivars varied significantly for growth, and flowering parameters. Among the various cultivars tested, the longest spike length was recorded in the cultivar Shringar $(74.09 \mathrm{~cm})$ which was at par with cultivars Maxican single $(73.53 \mathrm{~cm})$ Arka Nirantara $(71.24 \mathrm{~cm})$ and Rajat Rekha $(71.03 \mathrm{~cm})$, where as the cultivar Swarn Rekha exhibited shortest spike length $(63.86 \mathrm{~cm})$. Number of florets per spike was found to be maximum in Vaibhav (32.32) followed and at par with Suvasini (31.32), Swarn Rekha (28.75) and Pearl double (28.58). The minimum number of florets per spike was found in cultivar Rajat Rekha (17.55) also noticed significant difference in floret number in varoius cultivars. The maximum number of spikes per hectare was recorded in Suvasini (184110) followed by Vaibhav (183731), Shringar (183219) and Arka Nirantara (182271). The minimum number of spikes per hectare was found in cultivar Swarn Rekha (130640).
\end{abstract}

Keyword: Tuberose, relative performance, growth, flowering.

Paper cited: Pal, V., Chandra, N. and Singh, O. (2018). Assessment of tuberose (Polianthes tuberosa 1.) cultivars used for spikes production under western Uttar Pradesh conditions. South Asian Journal of Food Technology and Environment, 4(1): 660-663.

\section{Introduction}

Among the ornamental bulbous plants, tuberose (Polianthes tuberosa L.) a member of Amaryllidaceae family occupies a very most selective and special position due to its sweet fragrance and long keeping quality of tuberose spikes (Sadhu and Bose, 1973). It has gained considerable popularity and widely grown for aesthetic, aromatic and commercial purposes. The flower spikes are excellent as cut flowers for table decoration bouquets and etc. The flowers oil of tuberose remains even today one of the most expensive perfumes raw material. It blooms profusely almost throughout the year and most artistic garlands and floral arrangement are made from its flowers (Vaze, 2000). The crop is very rich in its varietal wealth and exhibits enormous variability most of the varieties grown in India exotic ones which are imported without evaluating their performance under our Western Uttar Pradesh. Some pioneering Indian Institute like IIHR, Bangalore, IARI, New Delhi and NBRI, Lucknow (Uttar Pradesh) have developed varieties suitable to local conditions. Published reports on the range of genetic diversity existing for different quantization characters over the past decade are available in literature. However, there is dearth of information regarding the relation performance of Indian varieties. Hence the present study was conducted in western Uttar Pradesh. Since, the demand for cut and loose flowers of tuberose is a rapidly increasing in the current year, the performance of production 
techniques in tuberose crop on the commercial basis need to be explored.

\section{Materials and Methods}

The field experiment comprising eight cultivars was conducted at Research Farm, under crop cafeteria unit, Krishi Vigyan Kendra, Hastinapur, Sardar Vallabhbhai Patel University of Agriculture \& Technology, Meerut (UP) during the year summer season of 2014-15 to 2015-16. The experiment was laid out in a Randomized Complete Block Design (RCBD) with three replications. Twenty five sprouted bulbs of each variety were planted in each replication. All recommended agronomic package and practice were followed to grown a successful crop. The observations on 12 characters were recorded from five randomly selected plants in each treatment of a replication except for the character days for fifty per cent sprouting. The bulbs were pre-treated with 0.15 per cent Hexaconazole $5 \%$ SC uniformly to prevent any fungal infection. The bulbs were planted in last week of March 2014-15 as well as in 2015-16 at the spacing of $30 \times 30 \mathrm{~cm}^{2}$ at 4 to $5 \mathrm{~cm}$. depth. Uniform package of practices were followed throughout the experiment to grow the healthy crops. Routine intercultural operations were done as per the requirement. Observations were made on various vegetative growth and flowering characters as well as applied. The data collected were analyzed using statistical method as suggested by Gomez and Gomez (2010).

\section{Results and Discussion}

\section{Assessment the performance of tuberose cultivars for growth characters}

Significant differences were observed in vegetative and flowering characters among the tuberose cultivars. There were significant differences among cultivars in respect to vegetative parameters from Table 1 , that cultivar Arka Nirantara recorded number of days taken to bulb sprouting earliest (14.50), followed by Swarn Rekha (14.53), whereas, the maximized days was recorded by Vaibhav (16.45). Maximum plant height was find in Suvasini $(36.23 \mathrm{~cm})$, followed by Vaibhav $(32.87 \mathrm{~cm})$, whereas the lowest was recorded by cultivar Mexican single $(30.59 \mathrm{~cm})$. Maximum number of leave per plant were recorded in Suvasini (56.63), followed by Vaibhav (53.93), while the minimum number of leave per plant was recorded under Swarn Rekha (32.59) and Number of leaves per plant varied from 32.59 (Swarn Rekha) to 56.63 (Suvasini). Longest leaf area were produced by Suvasini $\left(38.90 \mathrm{~cm}^{2}\right)$ cultivar, whereas Arka Nirantara recorded shortest leaf area $\left(29.23 \mathrm{~cm}^{2}\right)$. Maximum number of tillers per clumb were recorded in Vaibhav (9.66), followed by Arka Nirantara (8.16), while the minimum number of tillers per clumb was recorded under Swarn Rekha (5.33). Maximum of rachis length were recorded in Arka Nirantara $(31.77 \mathrm{~cm})$ followed by Mexican single $(31.03 \mathrm{~cm})$, while minimum rachis length was recorded under Swarn Rekha $(25.11 \mathrm{~cm})$. The varietal difference can be attributed to genetic makeup of the cultivars (Hemlata et al., 1992). Such variation in vegetative growth parameter of tuberose and gerbera cultivars has also been reported earlier Singh and Ramachandran (2002). Similar results on vegetative characters have also been reported by Behera et al., (1992) in chrysanthemum, gerbera and Mishra (1997) in gladiolus and tuberose.

\section{Assessment the performances of tuberose cultivars for flowering characters}

Tuberose cultivars varied significantly for quality and flowering parameters presented in Table 2 indicate that, the Vaibhav cultivar recorded number of days taken to first flowering earliest (30.68), followed by Rajat Rekha (30.79), whereas longest number of days taken to first flowering was recorded by Swarn Rekha (42.59). Maximum spike fresh weight was recorded in the cultivar Suvasini (72.49 g). Arka Nirantara and Mexican single recorded minimum spike fresh weight (59.22 g) and (59.45 g). and the longest 
$(74.09 \mathrm{~cm})$ spike length were produced by Shringar cultivar, whereas Mexican single recorded shortest spike length $(73.53 \mathrm{~cm})$ and the cultivars Rajat Rekha took minimum number of florets per spike (19.55) followed by Arka

Table 1: Assessment of Tuberose cultivars for growth characters under Western Uttar Pradesh.

\begin{tabular}{|c|c|c|c|c|c|c|}
\hline $\begin{array}{l}\text { Treatment } \\
\text { cultivars }\end{array}$ & $\begin{array}{l}\text { No. of days } \\
\text { taken to bulb } \\
\text { sprouting }\end{array}$ & $\begin{array}{l}\text { Plant height } \\
\text { (cm) }\end{array}$ & $\begin{array}{lr}\text { No. } & \text { of } \\
\text { leaves } & \text { per } \\
\text { plant } & \end{array}$ & $\begin{array}{l}\text { Leaf area } \\
\left(\mathrm{cm}^{2}\right)\end{array}$ & $\begin{array}{lr}\text { No. } & \text { of } \\
\text { tillers } & \text { per } \\
\text { clump } & \end{array}$ & $\begin{array}{l}\text { Rachis } \\
\text { length (cm) }\end{array}$ \\
\hline $\begin{array}{l}\text { Mexican } \\
\text { Single }\end{array}$ & 14.83 & 30.59 & 51.89 & 32.92 & 7.80 & 31.03 \\
\hline Arka Nirantara & 14.50 & 32.44 & 35.43 & 29.23 & 8.16 & 31.77 \\
\hline Shringar & 14.54 & 29.22 & 48.00 & 30.60 & 7.33 & 30.00 \\
\hline Pearl Double & 15.33 & 28.35 & 46.67 & 38.51 & 6.16 & 27.31 \\
\hline Suvasini & 15.40 & 36.23 & 56.63 & 38.90 & 7.90 & 25.33 \\
\hline Vaibhav & 16.45 & 32.87 & 53.93 & 37.50 & 9.66 & 26.84 \\
\hline Swarn Rekha & 14.53 & 32.25 & 32.59 & 32.04 & 5.33 & 25.11 \\
\hline Rajat Rekha & 14.83 & 32.44 & 51.27 & 29.64 & 6.00 & 30.61 \\
\hline $\mathrm{CD}$ at $5 \%$ & 1.76 & 3.26 & 7.18 & 3.87 & 1.15 & 2.97 \\
\hline
\end{tabular}

Table 2: Assessment of Tuberose cultivars for flowering characters under Western Uttar Pradesh

\begin{tabular}{|c|c|c|c|c|c|c|}
\hline $\begin{array}{l}\text { Treatment } \\
\text { cultivars }\end{array}$ & $\begin{array}{lr}\text { No. of } & \text { days } \\
\text { taken } & \text { to } \\
\text { flowering } & \end{array}$ & $\begin{array}{l}\text { Spike fresh } \\
\text { weight (g) }\end{array}$ & $\begin{array}{l}\text { Spike length } \\
(\mathrm{cm})\end{array}$ & $\begin{array}{lr}\text { No. } & \text { of } \\
\text { florets } & \text { per } \\
\text { spike } & \end{array}$ & $\begin{array}{lr}\text { No } & \text { of } \\
\text { spikes } & \text { per } \\
\text { clumb } & \end{array}$ & $\begin{array}{l}\text { No. of spikes } \\
\text { per hectare }\end{array}$ \\
\hline $\begin{array}{l}\text { Mexican } \\
\text { Single }\end{array}$ & 37.05 & 59.45 & 73.53 & 22.34 & 1.65 & 166324 \\
\hline Arka Nirantara & 36.38 & 59.22 & 71.24 & 21.00 & 1.60 & 182271 \\
\hline Shringar & 36.98 & 60.06 & 74.09 & 22.34 & 1.77 & 183219 \\
\hline Pearl Double & 37.28 & 69.47 & 69.50 & 29.58 & 1.56 & 144720 \\
\hline Suvasini & 41.02 & 72.49 & 64.68 & 31.32 & 1.43 & 184110 \\
\hline Vaibhav & 30.68 & 70.25 & 68.69 & 32.33 & 1.48 & 183731 \\
\hline Swarn Rekha & 42.59 & 70.33 & 63.86 & 28.75 & 1.55 & 130640 \\
\hline Rajat Rekha & 30.79 & 67.90 & 71.03 & 19.55 & 1.33 & 147340 \\
\hline CD at $5 \%$ & 3.96 & 4.11 & 4.29 & 1.76 & 0.08 & 1246.86 \\
\hline
\end{tabular}

Nirantara (21.00) and they are at par. Maximum number of florets per spike was recorded in the cultivar Vaibhav (32.33) followed by cultivars Suvasini (31.32) and Pearl double (29.58). The maximum number of spike per clumb under cultivar (1.77) was produced by Shringar followed by Mexican single (1.65) and Arka Nirantara (1.60), while the minimum number of spike per clumb under the cultivar Rajat Rekha (1.33). The higher production such as number of spikes per hectare was recorded in the cultivar
Suvasini (184110 Nos.) followed by Vaibhav (183731 Nos.), while the minimum number of spikes per hectare was recorded in cultivar Swarna Rekha (130640 Nos.).

Data presented in clearly indicated that assessment of tuberose to withering of first opened floret and flowering duration due to increased protein synthesis, rapid nutrient mobilization and prevention of chlorophyll degradation reported by Quinlan and Weaver (1969). The longest flowering duration may also 
be due to high vegetative growth and more number of florets and spike length reported by Beena and Mercy, (2003).

\section{Conclusion}

Out of the eight cultivars, most attractive was found in Suvasini and Vaibhav which have higher acceptability in the market. Based on the performance, Suvasini and Vaibhav have been identified as the most suitable cultivars for western Uttar Pradesh conditions. The results of the experiment revealed that Suvasini, Vaibhav and Shringar performed better compared to other tuberose cultivars.

\section{References}

1. Beena and Mercy, S.T. (2003). Effect of growth regulators on the growth and flowering of Anthurium. Indian Journal of Plant Physiology, 656-660.

2. Behera, T.K., Sirohi, P.S. and Anand, P. (1992). Assessment of Chrysanthemum germplasm for commercial cultivation under Delhi conditions. Journal of Ornamental Horticulture, 5 (1): 11-14.

3. Gomez, K.A. and Gomez, A.A. (2010). Statistical Procedure for Agricultural
Research. Wiley India (P) Limited, New Delhi.

4. Hemlata, Patel, B.A.A. and Nalwaadi, U.G. (1992). Variability studies in tuberose. Progressive Horticulture, 24 (1): 55-59.

5. Mishra, R.L. (1997). Effect of growth regulators on growth and flowering in tuberose under north Indian conditions. Indian Journal of Horticulture, 66 (4): 502507.

6. Quinlan, J.D. and Weaver, R.J. (1969). Influence of benzyladenine, leaf darkening and ringing on movement of Vitis vinifera. Plant Physiology, 44: 1247-1252.

7. Sadhu, M.K. and Bose, T.K. (1973). Tuberose for most artistic garland. Indian Horticulture, 18 (3): 17-20.

8. Singh, K.P. and Ramachandran, N. (2002). Comparison of greenhouse having natural ventilated and fan pad evaporative cooling system for gerbera production. Journal of Ornamental Horticulture, 5 (2): 15-19.

9. Voze, S.V. (2000). Indian essential oil industry: present and future. Journal of medicinal aromatic plant science, 22 (1): 186-191.

$\begin{array}{ll}\text { Received } & \text { : Feb., } 2018 \\ \text { Revised } & \text { : May, } 2018 \\ \text { Published } & \text { : June, } 2018\end{array}$

